\title{
Bacterial Diversity in the Saliva of Patients with Different Oral Hygiene Indexes
}

\author{
Juliana Vianna PEREIRA ${ }^{1}$ \\ Luciana LEOMIL ${ }^{1,2}$ \\ Fabíola RODRIGUES-ALBUQUERQUE ${ }^{1}$ \\ José Odair PEREIRA ${ }^{1}$ \\ Spartaco ASTOLFI-FILHO ${ }^{1}$ \\ ${ }^{1}$ Multidisciplinary Support Center, UFAM - Federal University of Amazonas, Manaus, AM, Brazil \\ ${ }^{2} U L B R A$ - Lutheran University Center of Manaus, Manaus, AM, Brazil
}

\begin{abstract}
The objective of the present study was to evaluate the bacterial diversity in the saliva of patients with different oral hygiene indexes using of two 16S rRNA gene libraries. Each library was composed of samples from patients with different averages of the differentiated Silness-Löe biofilm index: the first library (A) with an index between 1.0 and 3.0 (considered a high index) and the second library (B) between 0 and 0.5 (considered a low index). Saliva DNA was extracted and the 16S rRNA gene was amplified and cloned. The obtained sequences were compared with those stored at NCBI and RDP GenBank. The saliva of patients with high index presented five known genera - Streptococcus, Granulicatella, Gemella, Veillonella and Peptostreptococcus - and 33.3\% of nonculturable bacteria grouped into 23 operational taxonomic units (OTUs). The saliva of patients with low index differed significantly from the first library $(\mathrm{p}=0.000)$ and was composed of 42 OTUs distributed into 11 known genera - Streptococcus, Granulicatella, Gemella, Veillonella, Oribacterium, Haemophilus, Escherichia, Neisseria, Prevotella, Capnocytophaga, Actinomyces - including $24.87 \%$ of nonculturable bacteria. It was possible to conclude that there is greater bacterial diversity in the saliva of patients with low dental plaque in relation to patients with high dental plaque.
\end{abstract}

Key Words: bacterial diversity, 16S rRNA gene, saliva, dental biofilm.

\section{INTRODUCTION}

The oral cavity consists of a humid environment with a relatively constant temperature between 34 and $36^{\circ} \mathrm{C}$, neutral $\mathrm{pH}$, and shelters a large variety of microorganisms due to its numerous anatomical structures. This complex microbiota has been intensively studied, especially in the saliva, as it encompasses a variety of microorganisms from different regions, such as the tongue and the subgingival and supragingival biofilms (1).

Using a molecular approach in microbial investigation, it is believed that the number of microbial species that actually colonize the oral cavity may double in relation to the number previously detected species using culture-dependent methods, possibly even reaching 700 microbial species (2).

In light of these facts, many researchers have used molecular tools to differentiate healthy patients from those with periodontopathies (1), in order to detect the difference between oral sites (3), and to assess the microbiota of endodontic infections (4).

On the other hand, oral hygiene habits may also influence oral microbiota qualitatively and quantitatively $(5,6)$. This was the focus of this research, which investigated the microbial diversity in the saliva of patients with different accumulation of dental biofilm by using a molecular approach.

\section{MATERIAL AND METHODS}

\section{Subjects}

Thirty patients were fully oriented about the research objectives and agreed to sign an informed consent form after study approval by the Ethics

Correspondence: Dra. Juliana Vianna Pereira, Faculdade de Odontologia, Universidade Federal do Amazonas, Avenida Ministro Waldemar Pedrosa 1539, Bairro Praça 14 de Janeiro, 69025-050 Manaus, AM, Brasil. Tel: +55-92-33054910. e-mail: juvpereira@ufam.edu.br 
Committee of the Federal University of Amazonas (UFAM), Brazil. Patients over 18 years of age with at least 4 teeth were included in this study. Patients with history of immunosuppression, systemic diseases (e.g. diabetes and HIV), using medications that reduce saliva flow, pregnant women, and those under treatment with antimicrobials in the previous three months were excluded from the study. The participants were evaluated in terms of their dental biofilm index, according to the criteria of Silness-Löe (7) and divided into two groups. The first group (group A) was composed of 15 patients (6 males and 9 females, with ages between 23 and 67) with an average dental biofilm $\geq 1$. The second group (group B) was composed of 15 patients (4 male and 11 female, with ages between 20 and 43 years) with an average dental biofilm $\leq 0.5$.

\section{Sample Collection and DNA Extraction}

Saliva aliquots of $1 \mathrm{~mL}$ were collected in sterilized plastic tubes containing $500 \mu \mathrm{L}$ of TE buffer $(10 \mathrm{mM}$ Tris $\mathrm{HCl}, 1 \mathrm{mM}$ EDTA, $\mathrm{pH} 8.0$ ), after a stimulus of chewing on $1 \mathrm{~g}$ of paraffin. The samples were incubated at $56^{\circ} \mathrm{C}$ for $2 \mathrm{~h}$ in a buffer containing $10 \%$ Tween 20 and proteinase $\mathrm{K}(10 \mathrm{mg} / \mathrm{mL})$, and boiled for $10 \mathrm{~min}$. Next, the DNA was extracted by the phenol-chloroform (1:1) method, precipitated with $70 \%$ ethanol and resuspended in $40 \mu \mathrm{L}$ of TE buffer (8).

\section{PCR Amplification}

The 16S rRNA region was amplified with the primers 530F (5' - TTG GAG AGT TTG ATC CTG GCT C - 3') and 1492 Reverse (5' - ACG TCA TCC CCA CCT TCC TC - 3 '), and resulted in a final reaction volume of $25 \mu \mathrm{L}(50 \mathrm{mM} \mathrm{MgSO} 4,0.5 \mu \mathrm{L}$ of $10 \mathrm{mM}$ dNTPs, 5 pmol of each primer, $1.25 \mathrm{U}$ of Platinum Taq DNA polymerase High Fidelity, 10x buffer). The amplification cycle consisted in an initial denaturation at $94^{\circ} \mathrm{C}$ for $2 \mathrm{~min}$, followed by 35 cycles of template strand denaturation at $94^{\circ} \mathrm{C}$ for $30 \mathrm{~s}$, pairing of initiators at $58^{\circ} \mathrm{C}$ for $30 \mathrm{~s}$, and extension at $68^{\circ} \mathrm{C}$ for $1 \mathrm{~min}$, with a final extension at $68^{\circ} \mathrm{C}$ for $5 \mathrm{~min}$.

\section{$16 S$ rRNA Gene Clone Library Analysis}

The amplicons of each group were combined to form two libraries. The kit "TOPO TA Cloning for sequencing” (Invitrogen ${ }^{\circledR}$, Carlsbad, CA, USA) was used for cloning, while the kit "Transforming One Shot Mach - T1 Competente Cell” (Invitrogen ${ }^{\circledR}$ ) was used for Escherichia coli transformation, according to the manufacturer's instructions. Plasmid DNA was extracted (9) from randomly selected recombinant clones $(1,930$ for Library A and 4,500 for Library B), and used as template for sequencing. The sequencing reaction was constituted by $2 \mu \mathrm{L}$ of "DyEnamic Et Dye Terminator Cycle Sequencing Kit for Mega BACE" (Amersham Biosciences $^{\circledR}$; Little Chalfont, Buckinghamshire, UK), 100 ng of DNA, $1 \mu \mathrm{L}$ M13R initiator (5' - TAA TAC GAC TCA CTA TAG GG - 3') in the concentration of 5 $\mathrm{pmol} / \mu \mathrm{L}$, and autoclaved Milli-Q water to a final volume of $10 \mu \mathrm{L}$. The thermal cycle consisted of 35 cycles, as follows: denaturation of template strands at $95^{\circ} \mathrm{C}$ for 3 min, pairing of initiator at $95^{\circ} \mathrm{C}$ for $30 \mathrm{~s}$, and extension at $60^{\circ} \mathrm{C}$ for $30 \mathrm{~s}$, and a final extension at $60^{\circ} \mathrm{C}$ for $1 \mathrm{~min}$ and $20 \mathrm{~s}$. The sequences were analyzed in a MegaBACE capillary sequencer (Amersham - Biosciences ${ }^{\circledR}$ ), according to the manufacturer's recommendations.

The obtained sequences were processed for removal of contaminant vectors and low-quality nucleotides using the programs Phred/Cross-Match. The sequences were aligned and edited with the aid of Clustal W (10) and BioEdit 5.0.9 (11) softwares, respectively. Then, a genetic distance matrix was constructed using the Phylip 3.67 software (12) for subsequent analysis in the DOTUR (Distance Based OTU and Richness Determination) software (13), in order to calculate the richness estimate by the ACE, Chao1, Bootstrap and Jackknife methods, Shannon's diversity index, and Simpson's reciprocal index. The number of operational taxonomic units (OTUs) was estimated through the rarefaction method at the level of $97 \%$ similarity and considering an evolutionary distance of 0.03 . The taxonomic affiliation of the aligned sequences was performed with Bayesian rRNAClassifier software, from the "Ribosomal Database Project II" (RDP) database (14), and Basic Local Alignment Search Tool (BLAST) software, from the National Center of Biotechnology Information (NCBI) (15). A minimum of $98 \%$ similarity was considered for the encountered species.

\section{Statistical Analysis}

Statistical analysis was performed in relation to the degree of significant difference between nucleotide sequences by comparison of homologous curves using the S-LIBSHUFF sofware (16). 


\section{RESULTS}

For library A, 1,930 clones were obtained and 672 were selected for sequencing; for library B, 4,500 clones were obtained and 1,032 were selected for sequencing. After sequencing, vectors and lowquality nucleotides were removed, sequences were aligned and edited, and 153 of them were selected and considered valid for library A and 201 for library B. Calculation of the richness estimate through the ACE and CHAO1 methods, Shannon's diversity index, and Simpson's reciprocal index are represented in Table 1. The statistical analysis performed in relation to the degree of significant difference between the nucleotide sequences by comparing the homologous curves in the S-LIBSHUFF software indicated that the two libraries are mutually different $(\mathrm{p}=0.000)$.

The OTU richness estimate was inferred with the aid of DOTUR software in function of the evolutionary distance between sequences and the number of analyzed sequences (13), obtaining 23 OTUs for library A and 42 for library B. In Figure 1, ascendant curves with the tendency of reaching a plateau were observed for both libraries, especially library A. The richness estimate and diversity indexes showed differences between the two libraries: with the exception of Simpson's index, library $B$ always presented superior values (Table 1).

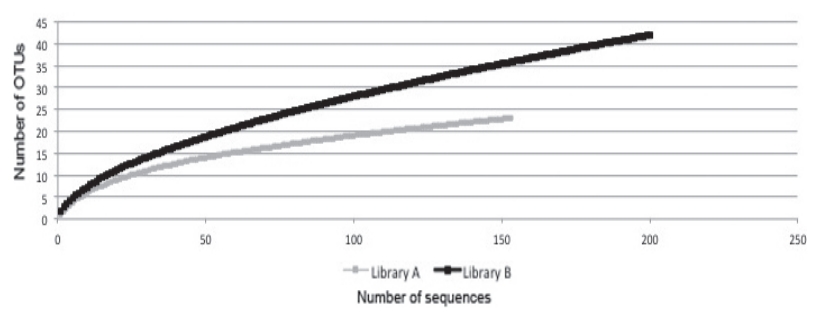

Figure 1. Rarefaction curves of the operational taxonomic units (OTUs) of the bacterial libraries from saliva A (gray line) and $\mathrm{B}$ (black line). $\mathrm{X}$ axis: number of sequences; $\mathrm{Y}$ axis: number of OTUs.
In terms of bacterial diversity, Streptococcus was the most prevalent genus in both libraries. In terms of species, library A presented a greater abundance of sequences corresponding to $S$. oralis followed by $S$. parasanguinis, while $S$. pneumoniae was more abundant in library B. The similarity found for genus and species, as well as the complete taxonomic affiliation of the studied sequences, are presented in Tables 2 and 3. The culturable microorganisms represented most of the studied sequences in both libraries. In library A, 51 of the 153 analyzed sequences did not present similarity with known species (33.3\%). This proportion was lower in library B, with 50 of the 201 analyzed sequences detected as nonculturable (24.87\%).

\section{DISCUSSION}

More than $99 \%$ of prokaryotes in the environment cannot be cultured in the laboratory, a phenomenon that limits our understanding of microbial physiology, genetics, and community ecology. One way around this problem is the culture-independent cloning and analysis of microbial DNA extracted directly from an environmental sample. Recent progresses in shotgun sequencing and computational methods for genome assembly have advanced the field of metagenomics to provide insights to the knowledge of uncultured microorganisms (13). Furthermore, several characteristics of the 16S rRNA gene, such as its essential function, ubiquity and evolutionary properties, have allowed it to become the most commonly used molecular marker in microbial ecology (case) and is a cost-effective method for characterization of oral bacterial communities (17).

The microbiota of the oral cavity has been the focus of many studies aiming to clarify the etiology of mouth infections. This microbiota has a significant impact on both the oral and general health. The salivary microbiota is a potential diagnostic indicator of several diseases (18). Analysis of sequences obtained from 16S

Table 1. Number of obtained and selected clones, validated sequences, operational taxonomic unit (OTU) richness estimates, and diversity indexes calculated for libraries A and B.

\begin{tabular}{lcccccccccc}
\hline Library & $\begin{array}{c}\text { Obtained } \\
\text { clones }\end{array}$ & $\begin{array}{c}\text { Selected } \\
\text { clones }\end{array}$ & $\begin{array}{c}\text { Valid } \\
\text { sequences }\end{array}$ & OTUs & ACE & Chaol & Jackknife & Bootstrap & Simpson & Shannon \\
\hline A & 1930 & 672 & 153 & 23 & 39.0031 & 32 & 33 & 27.2235 & 0.159615 & 2.31024 \\
B & 4500 & 1032 & 201 & 42 & 103.332 & 102 & 118.502 & 518.886 & 0.100846 & 279.908 \\
\hline
\end{tabular}


Table 2. Taxonomic classification of the library A sequences.

\begin{tabular}{|c|c|c|c|c|c|c|c|c|c|c|c|c|}
\hline Phylum & $(\mathrm{N}) \%$ & Class & $(\mathrm{N}) \%$ & Order & (N) $\%$ & Family & $(\mathrm{N}) \%$ & Genus & $(\mathrm{N}) \%$ & Species & $\mathrm{N}$ & $\%$ \\
\hline \multirow{23}{*}{ Firmicutes } & $(153)$ & Bacilli & (137) & J actobacillales & (134) & Strentococcacea & $(121)$ & Strentocoсcus & $(121)$ & S oralis & 24 & 1560 \\
\hline & 100 & Bacinl & 90 & Lactobacillales & 87.58 & Streptococcaceae & 79.08 & Streptococcus & 79.08 & S. oralls & 24 & 15.69 \\
\hline & & & & & & & & & & $\begin{array}{c}S . \\
\text { parasanguinis }\end{array}$ & 8 & 5.23 \\
\hline & & & & & & & & & & S. $s p$ & 34 & 22.22 \\
\hline & & & & & & & & & & S. sanguinis & 1 & 0.65 \\
\hline & & & & & & & & & & $\begin{array}{c}S . \\
\text { pneumoniae }\end{array}$ & 9 & 5.88 \\
\hline & & & & & & & & & & S. mitis & 4 & 2.61 \\
\hline & & & & & & & & & & S. gordonii & 4 & 2.61 \\
\hline & & & & & & & & & & S. cristatus & 2 & 1.31 \\
\hline & & & & & & & & & & S. salivarius & 2 & 1.31 \\
\hline & & & & & & & & & & $\begin{array}{c}\text { S. } \\
\text { thermophilus }\end{array}$ & 1 & 0.65 \\
\hline & & & & & & & & & & $\begin{array}{l}\text { Uncultured } \\
\quad S . s p\end{array}$ & 21 & 13.73 \\
\hline & & & & & & & & & & $\begin{array}{l}\text { Uncultured } \\
\text { bacterium }\end{array}$ & 11 & 7.19 \\
\hline & & & & & & Carnobacteriaceae & $\begin{array}{l}(7) \\
4.58\end{array}$ & Granulicatella & $\begin{array}{c}(7) \\
4.58\end{array}$ & $\begin{array}{l}\text { G. para- } \\
\text { adiacens }\end{array}$ & 3 & 1.96 \\
\hline & & & & & & & & & & $\begin{array}{l}\text { Uncultured } \\
\quad G . s p\end{array}$ & 4 & 2.61 \\
\hline & & & & & & Not rated & $\begin{array}{c}(6) \\
3.92\end{array}$ & Not rated & $\begin{array}{c}(6) \\
3.92\end{array}$ & $\begin{array}{l}\text { Uncultured } \\
\text { bacterium }\end{array}$ & 6 & 3.92 \\
\hline & & & & Bacillales & $\begin{array}{c}(2) \\
1.31\end{array}$ & Incertae Sedis XI & $\begin{array}{l}(2) \\
1.31\end{array}$ & Gemella & $\begin{array}{l}(2) \\
1.31\end{array}$ & $\begin{array}{l}\text { Uncultured } \\
\quad G . s p\end{array}$ & 2 & 1.31 \\
\hline & & & & Not rated & $\begin{array}{l}(1) \\
0.65\end{array}$ & Not rated & $\begin{array}{l}(1) \\
0.65\end{array}$ & Not rated & $\begin{array}{c}(1) \\
0.65\end{array}$ & $\begin{array}{l}\text { Uncultured } \\
\text { bacterium }\end{array}$ & 1 & 0.65 \\
\hline & & Clostridia & $\begin{array}{c}(16) \\
10\end{array}$ & Clostridiales & $\begin{array}{c}(16) \\
10.46\end{array}$ & Veillonellaceae & $\begin{array}{l}(3) \\
1.96\end{array}$ & Veillonella & $\begin{array}{l}(3) \\
1.96\end{array}$ & V. $s p$ & 2 & 1.31 \\
\hline & & & & & & & & & & $\begin{array}{c}\text { Uncultured } \\
\quad V \cdot s p\end{array}$ & 1 & 0.65 \\
\hline & & & & & & Peptostreptococcaceae & $\begin{array}{c}(13) \\
8.5\end{array}$ & Peptostreptococcus & $\begin{array}{l}(13) \\
8.50\end{array}$ & P. $s p$ & 3 & 1.96 \\
\hline & & & & & & & & & & P. stomatis & 5 & 3.27 \\
\hline & & & & & & & & & & $\begin{array}{c}\text { Uncultured } \\
P . s p\end{array}$ & 5 & 3.27 \\
\hline
\end{tabular}


rRNA libraries was used to investigate and compare bacterial diversity in the saliva of patients with distinct oral health conditions.

The Chao1 method uses the number of species that occurs one or a few times to estimate the number of unknown species (19). The estimated value for library B was superior to the one for library A, since the unique sequences represented half of the diversity found in the saliva of patients with a low dental biofilm index (Table 3).

In turn, the ACE estimator, based on abundance coverage, separates the observed species into groups of rare species (with only one representative or less than 10 representatives) or abundant species (with more than 10 representatives), using the rare species group to estimate the number of existing species (19). Thus, its value was expected to be superior in library $\mathrm{B}$ because it presents a large number rare or unique sequences that counterbalance with abundant species, such as Streptococcus sp, S. oralis, and S. pneumoniae (Table 3).

Simpson's and Shannon's diversity indexes use independent mathematical approximations to measure diversity. Shannon's index considers richness or different numbers of species found in different areas and equitability, or similarity, of organism distribution, which is superior in library B. Simpson's index calculation gives greater weight to the more abundant species, and the addition of rare species hardly causes any significant change in its value (20); thus, this index was superior in library A, where rare species represent the minority of the species found in the analysis (Table 2), unlike library $\mathrm{B}$, which contains rare and abundant species distributed more uniformly (Table 3).

Bootstrap estimates are based on subsamples of the OTU set, considering the number of OTUs in function of the sample number (21). The Jackknife estimator only shows unique OTUs, superior in library B (Table 3).

Saliva shelters microorganisms that form dental biofilm through dynamic processes. The dental surface is normally covered by a noncellular protein layer called film and composed of salivary glycoproteins, phosphoproteins and lipids. The structure of this layer has a fundamental role in the composition of the initial microbiota of the dental biofilm because it is selective and determined by receptors that allow specific components of the bacterial surfaces (adesines) to recognize these sites. Therefore, the initial colonizers of the dental biofilm constitute a highly selective part of the oral microbiota, especially $S$. sanguinis, $S$. oralis and $S$. mitis, which together represent $95 \%$ of the Streptococcus genus and $56 \%$ of the total initial microbiota (22). Other bacteria found in this stage are represented by Actinomyces sp, Haemophilus $s p$ and Neisseria sp. The microbial succession that follows is a consequence of the alteration that the initial colonizers generate in the environment, making it susceptible to secondary colonizers, especially facultative or strictly anaerobic microorganisms due to the reduction of oxygen concentration. This can be observed in biofilms after 9 days development. The climax community is characterized by microbial homeostasis, which tends to eliminate previously absent invader species (22).

The library formed by group B, which presents the saliva bacterial diversity of patients with a dental biofilm index considered low, contains bacterial representatives observed in the beginning of biofilm formation. Eleven known genera were observed: Streptococcus, Granulicatella, Gemella, Veillonella, Oribacterium, Haemophilus Escherichia, Neisseria, Prevotella, Capnocytophaga and Actinomyces. In this library, Streptococcus totalized 148 of the 201 analyzed sequences, representing $73.63 \%$ of the observed diversity. Streptococcus constitutes 66 to $80 \%$ of the dental biofilm microbiota in a development period of 4 to $8 \mathrm{~h}$. The high index of Streptococcus observed in the beginning of dental biofilm formation is due to microbial adhesion specificity to the acquired film. Furthermore, it reflects the high proportion of these microorganisms in saliva. The first colonizers of dental biofilm are of great importance for biofilm phase succession (22).

The library formed by group A, which presents the saliva bacterial diversity of patients with a high dental biofilm index, seems to group a microbial community in succession or a mature community, since the observed diversity was smaller than in the library formed by group B, with five known genera: Streptococcus, Granulicatella, Gemella, Veillonella and Peptostreptococcus. Furthermore, this group presented a larger proportion of nonculturable bacteria (33.3\%). According to $\mathrm{Li}$ et al. (22), the proportion of facultative and strictly anaerobic microorganisms rises as the biofilm becomes more mature, which may justify the larger number of nonculturable bacteria.

In terms of bacterial diversity, Streptococcus was the most prevalent genus in both libraries. It is a universal characteristic of ecological communities that some species are extremely abundant, others only 


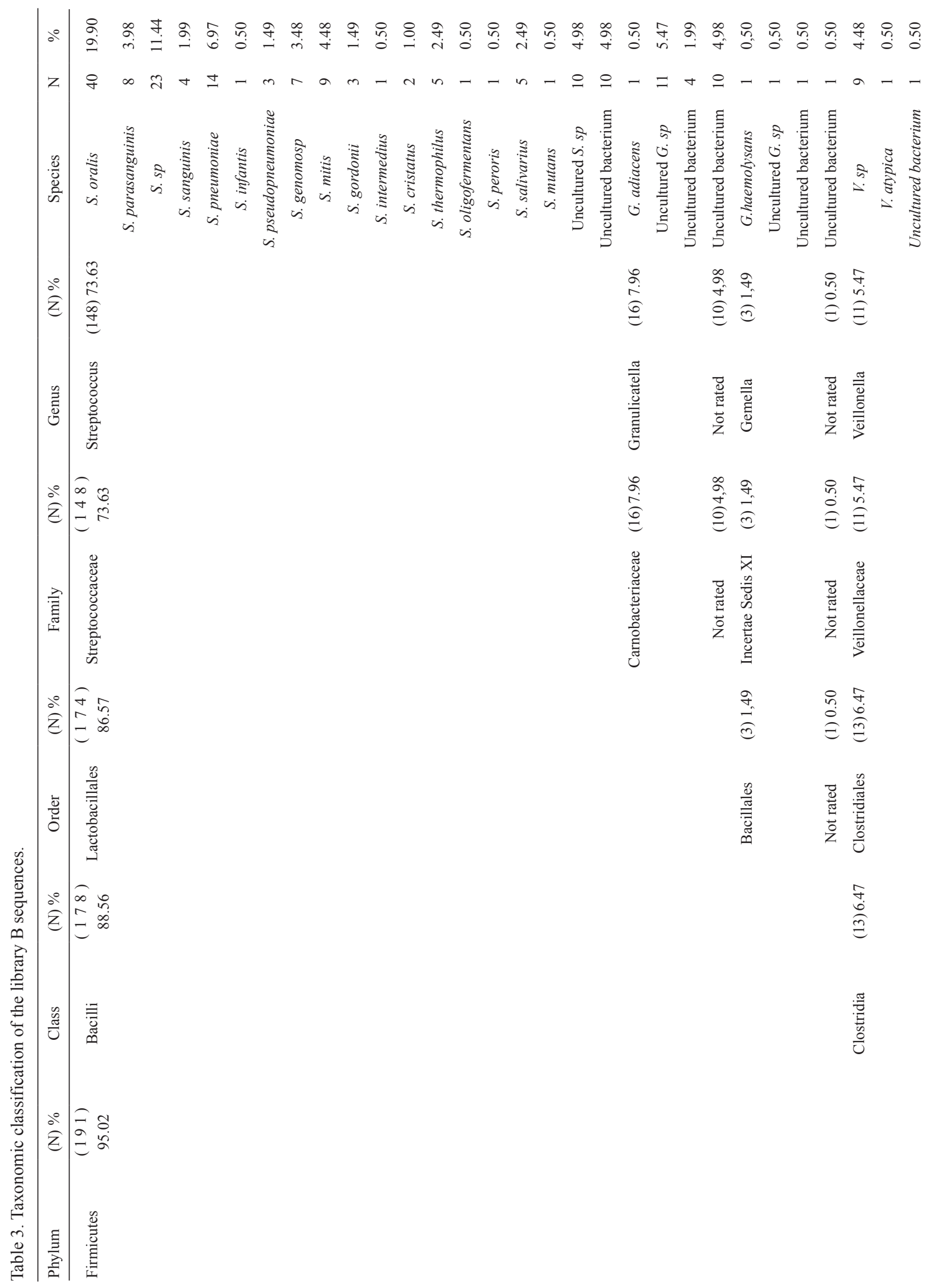




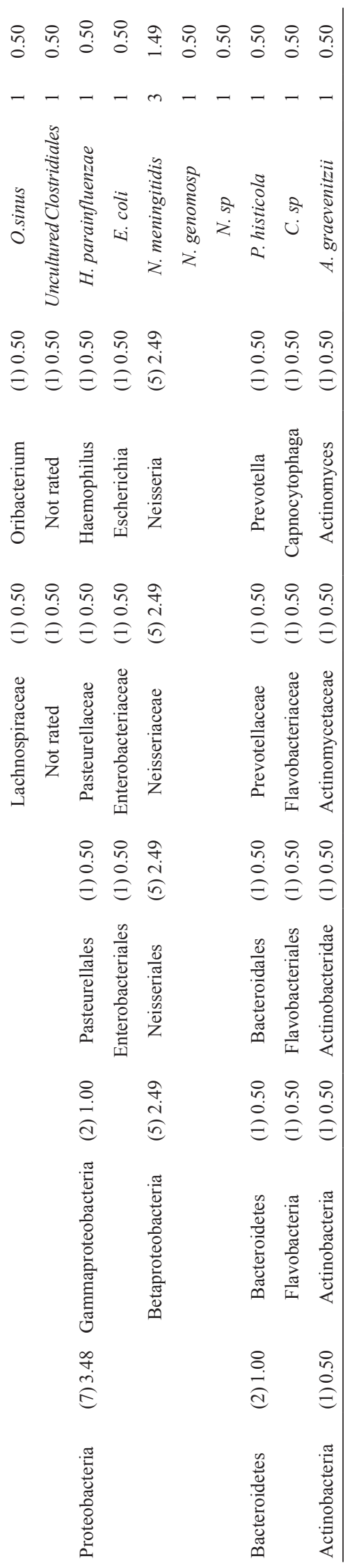

moderately common and the remainder, often the majority, rare (23).

A recent study characterized the bacterial communities in saliva and buccal mucosa of five healthy subjects to investigate the power of high throughput sequencing in revealing their diversity and biogeography patterns. Streptococcus mitis, S. mitis bv. 2 and G. haemolysans were the predominant species of the buccal epithelium (17). Veillonella parvula, Prevotella melaninogenica, Fusobacterium periodonticum and $S$. mitis as predominant microorganisms in the saliva of healthy individuals in previous studies $(3,17)$. Previous research demonstrated that 11 of the 25 most abundant organisms in saliva across individuals were uncultured 'species-level' phylotypes, belonging to the genera Prevotella, Porphyromonas, Streptococcus, Haemophilus, Aggregatibacter and Rothia (17), similar to the ones found in this study.

The knowledge and description of the bacterial genera found in the human oral cavity are paramount to form a base that sustains the study of the participation of these microorganisms in the ecology and pathology of the stomatognathic system, despite the role of dental plaque on the etiology of caries and periodontal diseases is well established in literature (24). The detection of microorganisms considered as nonculturable in the oral cavity indicates that many phylotypes are still unknown, which may reflect in an incomplete identification of the etiological agents of many oral diseases, considering that many are of polymicrobial origin (2), or are made up of commensal microorganisms with no pathological characteristic. Thus, the search for more knowledge regarding mouth microbiota in diverse hygiene conditions, as studied here, as well as regarding interferences of other previously studied factors or diseases, is still necessary. This idea was confirmed as nonculturable bacteria were observed in larger proportions in the group of patients with higher dental biofilm indexes (library A), and when nonclassified bacteria corresponded to a considerable proportion of studied pathologies, indicating that investigation of the oral microbiota must not be interrupted.

Certain diseases may be better understood in the future considering association between microorganisms, including those still unknown to science. According to Spor et al. (25), to measure the impact of host genetics on microbial diversity, it is useful to have an understanding of the factors that can influence variation of the microbiota in the absence of host genetic variation, as these environmental factors constitute the 'noise' that can mask host genetic effects. The data here presented contribute to the understanding of the oral cavity microbiota when oral hygiene conditions are considered, which had not been previously studied with a similar approach.

The libraries constructed in the present inveatigation constitute a pioneer survey of oral microbiology in the state of Amazonas, Brazil, and may be used in future investigations taking into consideration the characteristics of the region, especially including the peculiar and traditional feeding habits of the population. 


\section{RESUMO}

O objetivo do presente estudo foi avaliar a diversidade bacteriana da saliva de pacientes com diferentes índices de higiene bucal através da construção de duas bibliotecas do gene 16S rRNA. Cada biblioteca foi composta por amostras de saliva de pacientes com índice de biofilme dental de Silness-Löe diferenciado, sendo a primeira (A) com índice de 1,0 a 3,0 (denominada de alto índice) e a segunda (B), entre 0 a 0,5 (denominada de baixo índice). O DNA da saliva foi extraído e o gene 16S rRNA foi amplificado, clonado e sequenciado. As sequências obtidas foram comparadas com aquelas armazenadas no GenBank do NCBI e RDP. A saliva de pacientes com alto índice de biofilme dental apresentou cinco gêneros conhecidos: Streptococcus, Granulicatella, Gemella, Veillonella e Peptostreptococcus e $33,3 \%$ de bactérias não-cultivadas, agrupados em 23 unidades taxonômicas operacionais (UTOs). A saliva de pacientes com baixo índice de biofilme dental, foi diferente significativamente da primeira $(\mathrm{p}=0,000)$ e foi composta de 42 UTOs, distribuídas em 11 gêneros conhecidos: Streptococcus, Granulicatella, Gemella, Veillonella, Oribacterium, Haemophilus, Escherichia, Neisseria, Prevotella, Capnocytophaga, Actinomyces, além de $24,87 \%$ de bactérias não-cultivadas. Pode-se concluir que existe maior diversidade bacteriana na saliva de pacientes com baixo índice de biofilme dental em relação a pacientes com alto índice de biofilme dental.

\section{ACKNOWLEDGEMENTS}

This study received financial support from the National Council for Scientific and Technological Development (CNPq), Manaus Free Zone Superintendency (SUFRAMA), and Amazonas State Research Foundation (FAPEAM). The authors acknowledge technical support from Enedina Assunção and Jonso Souza.

\section{REFERENCES}

1. Sakamoto M, Umeda M, Ishikawa I, Benno Y. Comparison of the oral bacteria flora in saliva from a healthy subject and two periodontitis patients by sequence analysis of $16 \mathrm{~S}$ rDNA libraries. Microbiol Immunol 2000;44:643-652.

2. Tanner ACR, Izard J. Etiology of oral disease in view of microbial complexity. Oral Biosci Med 2005;2:209-213.

3. Mager DL, Ximenez-Fyvie LA, Haffajee AD, Socransky SS Distribution of selected bacterial species on intraoral surfaces. J Clin Periodontol 2003;30:644-654.

4. Saito D, Leonardo RT, Rodrigues JLM, Tsai SM, Hofling JF, Gonçalves RB. Identification of bacteria in endodontic infections by sequence analysis of $16 \mathrm{~S}$ rDNA clone libraries. J Med Microbiol 2006;55:101-107.

5. Haffajee AD, Teles RP, Socransky SS. The effect of periodontal therapy on the composition of the subgingival microbiota. Periodontol 2000 2006;42:219-258.

6. Tanwir F, Altamash M, Gustafsson A. Effect of diabetes on periodontal status of a population with poor oral health. Acta Odontol Scand 2009;67:129-133.
7. Silness J, Loe H. Periodontal disease in pregnancy II: correlation between oral hygiene and periodontal conditions. Acta Odontol Scand 1964;22:121-135.

8. Nogueira CAM, Momesso CAS, Machado RLD, Almeida MTG, Rossit ARB. Performance of commercial kits and laboratory protocols for bacterial genomic DNA extraction. Rev Panam Infectol 2004;6:35-38

9. Birnboim HC, Doly J. A rapid alkaline extraction procedure for screening recombinant plasmid DNA. Nucleic Acids Res 1979;24:1513-1523.

10. Thompson JD, Higgins DG, Gibson TJ. CLUSTALW: improving the sensitivity of progressive multiple sequence alignment through sequence weighting, positions-specific gap penalties and weight matrix choice. Nucleic Acids Res 1994;22:4673-4680.

11. Hall TA. BioEdit: a user-friendly biological sequence alignment editor and analysis program for Windows 95/98/NT. Nucl Acids Symp Ser 1999;41:95-98.

12. Felsenstein J. PHYLIP: Phylogenetic inference package. Version 3.67. Seattle. Department of Genetics, University of Washington 2007.

13. Schloss PD, Handelsman J. Introducing DOTUR, a computer program for defining Operational Taxonomic Units and Estimating Species Richness. Appl Environ Microbiol 2005;71:1501-1506.

14. Wang GQGM, Garrity JM, Tiedje JM, Cole JR. Naive Bayesian classifier for rapid assignment of rRNA sequences into the new bacterial taxonomy. Appl Environ Microbiol 2007;73:5261-5267.

15. Zhang Z, Schwartz S, Wagner L, Miller W. A greedy algorithm for aligning DNA sequences, J Comput Biol 2000;7:203-214.

16. Scholl P, Larget, BR, Handelsman J. Integration of microbial ecology and statistics: a test to compare gene libraries. Appl Environ Microbiol 2004;70:5485-5992.

17. Diaz PI, Dupuy AK, Abusleme L, Reese B, Obergfell C, Choquette $\mathrm{L}$, et al. Using high throughput sequencing to explore the biodiversity in oral bacterial communities. Mol Oral Microbiol 2012;27:182-201.

18. Lazarevic V, Whiteson K, Gaïa N, Gizard Y, Hernandez D, Farinelli L, et al.. Analysis of the salivary microbiome using culture-independent techniques. J Clin Bioinforma 2012;2:4.

19. Chao A, Ma MCV, Yang MCK. Stopping rules and estimation for recapture debugging with unequal failure rates. Biometrika 1993;80:193-201.

20. Buckland ST, Magurran AE, Green RE, Fewster RM. Monitoring change in biodiversity through composite indices. Philos Trans R Soc Lond B Biol Sci 2005;28;360:243-54.

21. Smith EP, van Belle G. Nonparametric estimation of species richness. Biometrics 1984;40:119-129.

22. Li J, Helmerhorst EJ, Leone CW, Troxler RF, Yaskell T, Haffajee $\mathrm{AD}$, et al.. Identification of early microbial colonizers in human dental biofilm. J Appl Microbiol 2004;97:1311-1318.

23. Magurran AE. Biological diversity. Curr Biol 2005 22;15:R116-R118.

24. Zanatta FB, Antoniazzi RP, Pinto TMP, Rosing CK. Supragingival plaque removal with and without dentifrice: a randomized controlled clinical trial. Braz Dent J 2012;23:235-240.

25. Spor A, Koren O, Ley R. Unravelling the effects of the environment and host genotype on the gut microbiome. Nat Rev Microbiol 2011;9:279-290.

Received June 29, 2010 Accepted September 16, 2011 